\title{
Stakeholders' perspectives on the operationalisation of the ecosystem service concept: Results from 27 case studies
}

Jan Dick ${ }^{\mathrm{a}, *}$, Francis Turkelboom ${ }^{\mathrm{b}}$, Helen Woods ${ }^{\mathrm{a}}$, Irene Iniesta-Arandia c, Eeva Primmer ${ }^{\mathrm{d}}$, Sanna-Riikka Saarela ${ }^{\mathrm{d}}$, Peter Bezák ${ }^{\mathrm{e}}$, Peter Mederly ${ }^{\mathrm{f}}$, Michael Leone $^{\mathrm{b}}$, Wim Verheyden ${ }^{\mathrm{b}}$,

Eszter Kelemen ${ }^{\mathrm{g}, \mathrm{h}}$, Jennifer Hauck ${ }^{\mathrm{i}, \mathrm{j}}$, Chris Andrews ${ }^{\mathrm{a}}$, Paula Antunes ${ }^{\mathrm{k}}$, Réka Aszalós ${ }^{1}$, Francesc Baró ${ }^{\mathrm{m}}$, David N. Barton ${ }^{\mathrm{n}}$, Pam Berry ${ }^{\circ}$, Rob Bugter ${ }^{\mathrm{p}}$, Laurence Carvalho ${ }^{\mathrm{a}}$, Bálint Czúcz ${ }^{\mathrm{l}, \mathrm{q}}$, Rob Dunford ${ }^{\mathrm{o}, \mathrm{r}}$, Gemma Garcia Blanco ${ }^{\mathrm{s}}$, Nicoleta Geamana ${ }^{\mathrm{t}}$, Relu Giuca ${ }^{\mathrm{t}}$, Bruna Grizzetti ${ }^{\text {u }}$, Zita Izakovicová ${ }^{v}$, Miklós Kertész ${ }^{1}$, Leena Kopperoinen ${ }^{\mathrm{d}}$, Johannes Langemeyer

${ }^{m}$, David Montenegro Lapola ", Camino Liquete ", Sandra Luque ${ }^{\mathrm{x}}$, Guillermo Martínez Pastur $^{\mathrm{y}}$, Berta Martin-Lopez ${ }^{\mathrm{z}}$, Raktima Mukhopadhyay ${ }^{\text {aa }}$, Jari Niemelä ${ }^{\text {ab }}$, David Odee ${ }^{\text {ac }}$, Pablo Luis Peri ad,ae,af, Patricia Pinho ${ }^{\text {ag }}$, Gleiciani Bürger Patrício-Roberto ${ }^{w}$, Elena Preda ${ }^{t}$, Joerg Priess ${ }^{\mathrm{i}}$, Christine Röckmann ${ }^{\text {ah }}$, Rui Santos ${ }^{\mathrm{k}}$, Diana Silaghi ${ }^{\text {ai }}$, Ron Smith ${ }^{\mathrm{a}}$, Angheluta Vadineanu ${ }^{\mathrm{t}}$, Jan Tjalling van der Wal ${ }^{\text {ah }}$, Ildikó Arany ${ }^{1}$, Ovidiu Badea ${ }^{\text {ai }}$, Györgyi Bela ${ }^{\text {g,aj }}$, Emil Boros ${ }^{1}$, Magdalena Bucur ${ }^{\mathrm{t}}$, Stefan Blumentrath ${ }^{\mathrm{n}}$, Marta Calvache ${ }^{\mathrm{k}}$, Esther Carmen ${ }^{\mathrm{a}}$, Pedro Clemente ${ }^{k}$, João Fernandes ${ }^{k}$, Diogo Ferraz ${ }^{k}$, Claudia Fongar ${ }^{\text {ak }}$, Marina GarcíaLlorente ${ }^{\text {al, c, }}$, Erik Gómez-Baggethun ${ }^{\text {am,n,m }}$, Vegard Gundersen ${ }^{\text {an }}$, Oscar Haavardsholm ${ }^{\text {ao }}$, Ágnes Kalóczkai ${ }^{1}$, Thalma Khalalwe ${ }^{\text {ac }}$, Gabriella Kiss ${ }^{\mathrm{h}}$, Berit Köhler ${ }^{\text {an }}$, Orsolya Lazányi ${ }^{\mathrm{g}, \mathrm{h}}$,

Eszter Lellei-Kovács ${ }^{1}$, Rael Lichungu ${ }^{\text {ac }}$, Henrik Lindhjem ${ }^{\text {ao }}$, Charles Magare ${ }^{\text {ac }}$, Jyri Mustajoki ${ }^{\mathrm{d}}$, Charles Ndege ${ }^{\mathrm{ac}}$, Megan Nowell ${ }^{\mathrm{n}}$, Sergi Nuss Girona ${ }^{\text {ap }}$, John Ochieng ${ }^{\text {ac }}$, Anders Often ${ }^{\mathrm{n}}$, Ignacio Palomo ${ }^{\text {aq }}$, György Pataki ${ }^{\mathrm{g}, \mathrm{h}}$, Rasmus Reinvang ${ }^{\mathrm{ao}}$, Graciela Rusch ${ }^{\text {ar }}$, Heli Saarikoski ${ }^{\mathrm{d}}$, Alison Smith ${ }^{\circ}$, Emma Soy Massoni ${ }^{\mathrm{a}} \mathrm{p}$, Erik Stange ${ }^{\text {an }}$, Nora Vågnes Traaholt ${ }^{\text {as }}$, Ágnes Vári ${ }^{1}$, Peter Verweij ${ }^{\mathrm{p}}$, Suvi Vikström ${ }^{\mathrm{d}}$, Vesa Yli-Pelkonen ${ }^{\text {ab }}$, Grazia Zulian $^{u}$

a Centre for Ecology and Hydrology, Midlothian, UK

b Research Institute for Nature and Forest (INBO), Brussels, Belgium

c Social-ecological Systems Lab, Department of Ecology, Universidad Autónoma de Madrid, Spain

d Finnish Environment Institute, Helsinki, Finland

e Institute of Landscape Ecology, Slovak Academy of Sciences, Slovakia

f Department of Ecology and Environmental Sciences, Constantine the Philosopher University, Slovakia

g Environmental Social Science Research Group (ESSRG Ltd.), Budapest, Hungary

h Department of Decision Sciences, Corvinus University of Budapest, Hungary

i Helmholtz-Centre for Environmental Research - UFZ, Leipzig, Germany

j CoKnow Consulting - Coproducing Knowledge for Sustainability, Jesewitz, Germany

k CENSE - Centre for Environmental and Sustainability Research, Faculdade de Ciências e Tecnologia, Universidade Nova de Lisboa, Portugal

1 Institute of Ecology and Botany, MTA Centre for Ecological Research, Hungary

m Institute of Environmental Science and Technology (ICTA), Universitat Autònoma de Barcelona (UAB),

Edifici Z (ICTA-ICP), Barcelona, Spain

n Norwegian Institute for Nature Research (NINA), Oslo, Norway

o Environmental Change Institute, Oxford, UK

p Wageningen University and Research, Environmental Research (Alterra), The Netherlands

q European Topic Centre on Biological Diversity, Muséum national d'Histoire naturelle, Paris, France

r Centre for Ecology \& Hydrology, Oxfordshire, UK

s Urban Environment and Territorial Sustainability Area, Energy and Environment Dividision, Spain 
t University of Bucharest - Research Center in Systems Ecology and Sustainability, Romania

u European Commission - Joint Research Centre (JRC), Italy

v Institute of Landscape Ecology, Slovak Academy of Sciences, Bratislava, Slovakia

w UNESP - Universidade Estadual Paulista, Ecology Department - LabTerra, São Paulo, Brazil

x IRSTEA, National Research Institute of Science and Technology for Environment and Agriculture, UMR

TETIS, France

y Centro Austral de Investigaciones Científicas (CADIC CONICET), Tierra del Fuego, Argentina

z Leuphana University of Lüneburg, Faculty of Sustainability, Institute of Ethics and Transdisciplinary

Sustainability Research, Germany

aa IBRAD (Indian Institute of Bio Social Research and Development), West Bengal, India

ab Department of Environmental Sciences, University of Helsinki, Finland

ac Kenya Forestry Research Institute (KEFRI), Nairobi, Kenya

*Corresponding Author: jand@ceh.ac.uk (J. Dick)

\section{Accepted final draft version}

\section{Reference:}

Dick J, Turkelboom F, Woods H, Iniesta-Arandia I, Primmer E, Saarela S-R, Bezák P, Mederly P, Leone M, Verheyden W, Kelemen E, Hauck J, Andrews C, Antunes P, Aszalós R, Baró F, Barton DN, Berry P, Bugter R, Carvalho L, Czúcz B, Dunford R, Garcia Blanco G, Geamana N, Giuca R, Grizzetti B, Izakovicová Z, Kertész M, Kopperoinen L, Langemeyer J, Montenegro Lapola D, Liquete C, Luque S, Martínez Pastur G, Martin-Lopez B, Mukhopadhyay R, Niemelä J, Odee D, Luis Peri P, Pinho P, Bürger Patrício-Roberto G, Preda E, Priess J, Röckmann C, Santos R, Silaghi D, Smith R, Vadineanu A, Tjalling van der Wal J, Arany I, Badea O, Bela G, Boros E, Bucur M, Blumentrath S, Calvache M, Carmen E, Clemente P, Fernandes J, Ferraz D, Fongar C, García-Llorente M, GómezBaggethun E, Gundersen V, Haavardsholm O, Kalóczkai A, Khalalwe T, Kiss G, Köhler B, Lazányi $\mathrm{O}$, Lellei-Kovács E, Lichungu R, Lindhjem $\mathrm{H}$, Magare $\mathrm{C}$, Mustajoki J, Ndege $\mathrm{C}$, Nowell M, Nuss Girona S, Ochieng J, Often A, Palomo I, Pataki G, Reinvang R, Rusch G, Saarikoski $H$, Smith $A$, Soy Massoni $E$, Stange $E$, Vågnes Traaholt $N$, Vári $A$, Verweij $P$, Vikström S, Yli-Pelkonen V, Zulian G (2018) Stakeholders' perspectives on the operationalisation of the ecosystem service concept: Results from 27 case studies. Ecosystem Services 29: 552-565.

\section{https://doi.org/10.1016/i.ecoser.2017.09.015}

\section{Disclaimer:}

The PDF document is a copy of the final version of this manuscript that was subsequently accepted by the journal for publication. The paper has been through peer review, but it has not been subject to any additional copy editing or journal-specific formatting. It thus looks different from the final published version, which may be accessed following the DOI above. 


\begin{abstract}
The ecosystem service (ES) concept is becoming mainstream in policy and planning, but operational influence on practice is seldom reported. Here, we report the practitioners' perspectives on the practical implementation of the ES concept in 27 case studies. A standardised anonymous survey $(n=246)$, was used, focusing on the science-practice interaction process, perceived impact and expected use of the case study assessments. Operationalisation of the concept was shown to achieve a gradual change in practices: $13 \%$ of the case studies reported a change in action (e.g. management or policy change), and a further $40 \%$ anticipated that a change would result from the work. To a large extent the impact was attributed to a well conducted science-practice interaction process $(>70 \%)$. The main reported advantages of the concept included: increased concept awareness and communication; enhanced participation and collaboration; production of comprehensive science-based knowledge; and production of spatially referenced knowledge for input to planning (91\% indicated they had acquired new knowledge). The limitations were mostly case-specific and centred on methodology, data, and challenges with result implementation. The survey highlighted the crucial role of communication, participation and collaboration across different stakeholders, to implement the ES concept and enhance the democratisation of nature and landscape planning.
\end{abstract}

\title{
1. Introduction
}

The dual concepts of natural capital (NC) and ecosystem services (ES) have matured over the last 30 years and are becoming mainstream in policy and planning. Major global initiatives such as the Millennium Ecosystem Assessment (MA, 2005), The Economics of Ecosystems \& Biodiversity (TEEB, 2010), and the more recent Intergovernmental Platform on Biodiversity and Ecosystem Service (IPBES) (Díaz et al., 2015) have championed the concepts. The concepts are also becoming increasingly integrated in local-level decisionmaking, for example in urban planning (Kopperoinen et al. 2015; Maes et al., 2016), in national park management (Cairngorms National Park Authority, 2012, García-Llorente et al., 2016; Gómez-Baggethun et al., 2013; Palomo et al., 2014), and within river basin management plans (Grizzetti et al., 2016a).

In recent years there has been an exponential rise in the number of academic papers reporting aspects of the implementation, or so called operationalisation of the ES concept (see Jax et al., 2018). This includes work from the case study areas considered in this paper, which investigated: mapping ES (Baró et al., 2016; Clemente et al., 2015; García-Nieto et al., 2015; Liquete et al., 2015; Palomo et al., 2013), modelling ES (Baró et al., 2014; Liquete et al., 2016b), valuation assessments (Martín-López et al., 2014), and integrated assessment of ES (Langemeyer et al., 2016). In addition, issues of scale (Bezák et al., 2017; Kovács et al., 2015), temporal aspects (Dick et al., 2016), and the linkages between biodiversity and ES (Gonzalez-Redin et al., 2016; Liquete et al., 2016a) have been studied in the case studies. Stakeholder engagement (García-Nieto et al., 2015), governance (Primmer et al., 2015) and the linkages between ES and human wellbeing (Kelemen et al., 2015; Tenerelli et al., 2016) 
are arguably less well researched. In the literature there are many similar examples where researchers draw on theory-based argumentation, large datasets and/or case studies, to test the utility of the ES concept. However large scale case study comparisons on how the ecosystem service concept can be operationalised, and how the knowledge is applied in practical terms are lacking. Few studies have assessed the impact of such research on the ES knowledge users (Posner et al., 2016; Saarela and Rinne, 2016), whose perspectives are vital if we are to make these concepts useful in real-world planning and decision-making. This paper addresses the apparent knowledge gap in the systematic understanding of the usefulness of the ES concept for practitioners, by answering the question: In what ways does the ecosystem service concept help practitioners address their specific real-world, ecosystem management needs?
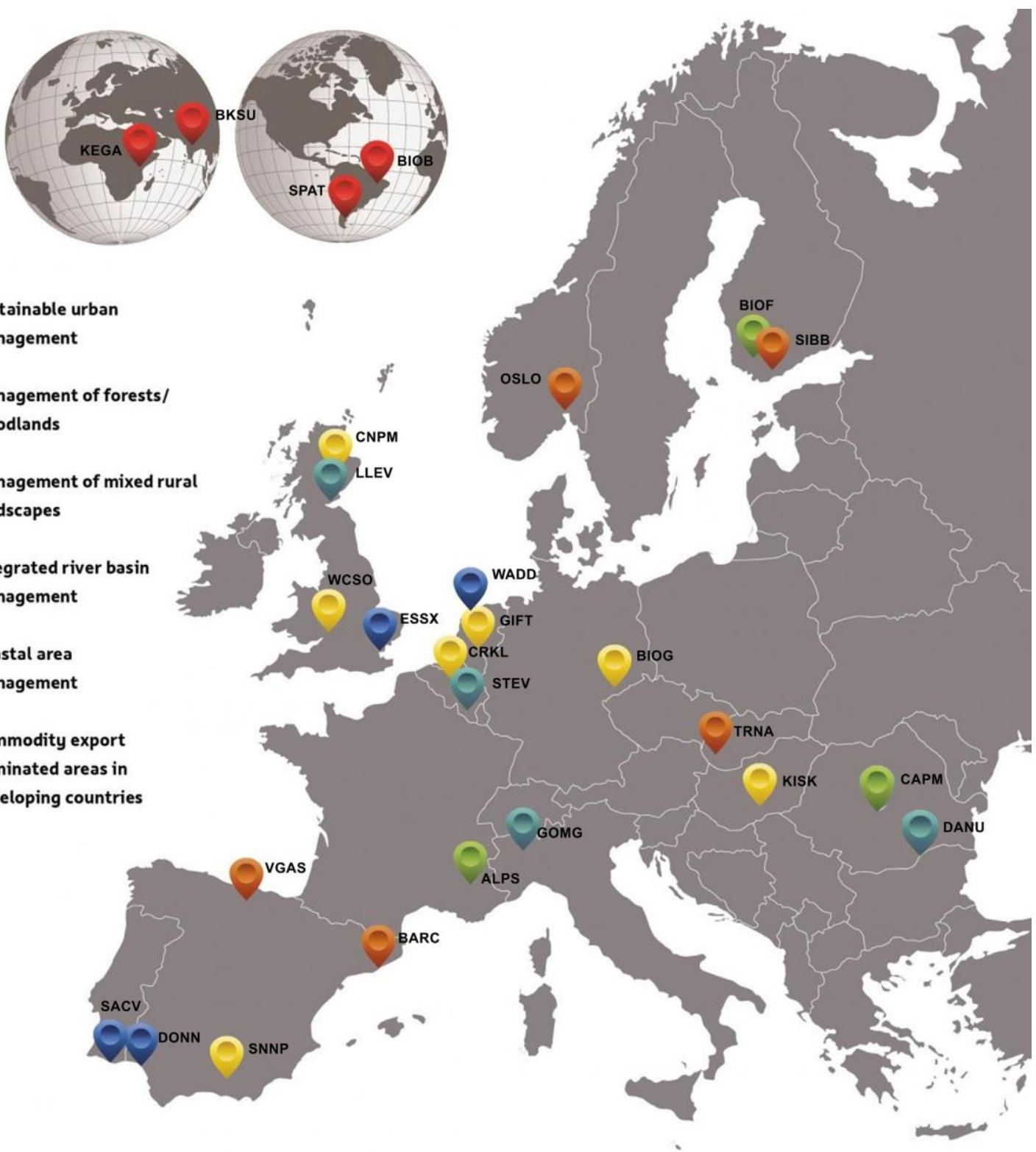

Fig. 1. Map showing the location of the 27 case studies, about which the 246 stakeholders' offered their perspectives on the advantages and disadvantages of the application of the ES concept. 
It is now acknowledged that the analysis of ES requires interdisciplinary approaches i.e. working across academic boundaries (Nesshöver et al., 2016). Despite the recent acknowledgment that funding bodies may discriminate against interdisciplinary research (Bromham et al., 2016), European funding streams are promoting not only interdisciplinary, but also transdisciplinary research (Lyall et al., 2015), which aims to integrate information from various scientific and societal bodies of knowledge (Hauck et al., 2015; Jahn et al., 2012; Lang et al., 2012; Röckmann et al., 2015). Transdisciplinary research offers conceptual and practical advances resulting from the synergy of different perspectives and contributions, which arguably are necessary for an ethical application of the ES concept to issues of societal relevance (Jax et al., 2013). The EU explicitly required a transdisciplinary approach to determine the advantages and limitations of the NC and ES concepts in real world situations, which is the focus of this paper. This paper reports the perspectives of users of ES knowledge in 27 case studies, following three years of ES research, addressing societally relevant ES issues selected by local stakeholders (Jax et al., 2018).

The case studies were co-developed with practitioners in a transdisciplinary way to ensure that they would address real-world practical concerns in the 27 localities. At an early stage in the ES research, the case studies assembled 'Case Study Advisory Boards' (CABs) (see Jax et al., 2018). The goal of the CABs was to provide a forum where practitioners could work closely with researchers to identify topics to be investigated, discuss appropriate methods and tools, and to decide collectively about the process. Researchers worked with practitioners to: (i) identify the advantages/disadvantages they faced in operationalising the ES concept in their specific policy and decision-making context; (ii) apply and refine the methods and models to the case study's needs; and (iii) test the method/model relevance and usefulness in an iterative manner. As such, each individual case addressed different issues and used varied methodological tools to address their specific challenges. This paper draws out and characterises common lessons learnt, with respect to the operational potential of the ES concept, from the perspectives of the practitioners and stakeholders within these case studies.

Cross-case study comparisons of the tools, methods and perceptions of stakeholders are not the purpose of this paper, but these analyses have been addressed in other literature (See Carmen et al., 2018; Priess et al., 2018; Smith et al., 2018; Turkelboom et al., 2018).

The design of the case studies reported in this study followed an approach described by Khagram et al. (2010), according to which the project or programme would constitute a "self-identified community of scholars who share research questions or problems and are working on an interlinked set of research projects". In line with the ideas of Khagram et al. (2010), the case studies explored three 'theories of knowledge' types, i.e. prediction (using models and scenarios; Hendriks et al., 2014), contextual situation-embedded understanding (e.g. analysis of conceptual frameworks; Dick et al., 2017; Liquete et al., 2016c), and explanation (through causal pathways e.g. photoseries analysis; Martínez Pastur et al., 2016; Tenerelli et al., 2017). 
Similarly, the design of the case studies followed ideas from the general literature on the philosophy of science (e.g. Kuhn 1962; Lakatos 1970), from which Khagram et al. (2010) derive three major meta-philosophies (or paradigms) of research programmes for interdisciplinary environmental research. The paradigms, positivism, interpretivism and constructivism, define the nature of the phenomena researched, and can be mapped to components of the case studies contributing to this paper. For example, part of the Norwegian urban case study, coded as OSLO (Supplementary Material 1), which tested tools related to neoclassical economics, can be judged to have followed a positivist philosophy of knowledge, whilst the case studies that focused on socio-cultural and especially narrative methods can be judged to follow the interpretivism paradigm (Dick et al., 2017; Kelemen et al., 2013). A primary goal of interpretivist research is to understand the subjective views of individual actors, and the inter-subjective shared views of communities of actors. Some of the case studies which used discourse-based approaches e.g. participatory or deliberative mapping of ecosystem services can be judged to have followed the ideas of constructivist philosophy of knowledge, which seeks to explain and understand how reality is construed through social and natural processes (Hendriks et al., 2014, Smith et al., 2018, Zulian et al., 2018). The aim of the case studies and the meta-philosophies adopted was co-designed with the CABs.

The CABs were also consulted on the design and implementation of the evaluation process which was carried out towards the end of the study. This process allowed the CAB members and other local stakeholders to contribute as respondents to a comprehensive anonymous survey, in order to address the knowledge gap identified i.e. practitioners' perspectives of the ES concept.

This paper reports an assessment of the case study stakeholders' perspectives on the application of the ES concept, and in particular their views on the advantages and limitations of this concept as implemented in their own case study. To determine the advantages and limitations of the ES concepts, we use a combination of statistical and comparative research strategies. We specifically consider what factors in the ES appraisal the practitioners considered were associated with a 'change in action' in their case study, as this was considered the end point of the research evaluated.

The paper is structured as follows: the characterisation of the case studies and the design and implementation of the questionnaire are reported in Section 2. The results are reported in Sections 3 and 4 derives the lessons learnt from testing the ES concept in real-world case studies, and discusses these in the context of the value of integrating stakeholders into ES appraisals and the advantages for wider societal change.

\section{Materials and methods}

\subsection{Characterisation of the case studies}


The 27 case studies, used as testing grounds for exploring the challenges and opportunities for operationalising the ES concept, covered a range of locations (Fig. 1). Twenty-three were located in Europe and an additional one each in India (BKSU), Kenya (KEGA), Argentina (SPAT) and Brazil (BIOB). Each case study was assigned a four letter code, which is listed alongside the full case study title in Supplementary Material 1.

Table 1. Settings and issues studied across the 27 case studies, as identified by the case study research teams. The order of the case studies reflects the major ecosystems in the case study area and corresponds to Fig. 1. Water, in this case, indicates freshwater bodies or rivers.



Details of all the case studies can be found in the 'Ecosystems in Operation case studies' brochure (EU FP7 OpenNESS Project 2016). The case studies were originally selected to represent a variety of landscapes and ecosystems specified by the commissioning body (EU) including urban areas, forests and woodlands, agricultural and mixed landscapes, rivers, lakes and coasts (Table 1).

A wide range of stakeholders were engaged in the case studies, including representatives of public agencies, natural resource management authorities, municipalities, and regional governments. Stakeholders in the form of ES users were also engaged, including land owners, farmers, foresters, urban dwellers, (eco)tourism business operators, tourists, NGOs etc.

Each case study explored one or more local societal issues which could be addressed by ES tools and approaches (Table 1). Given the diversity of settings, goals and issues, a wide selection of tools and methods were applied. An evaluation of some of these methods are detailed in other papers in this special issue (Barton et al., 2018; Dunford et al., 2018; Harrison et al., 2018; Priess et al., 2018; Smith et al., 2018; Zulian et al., 2018).

\subsection{Creation, structure and implementation of the standard questionnaire protocol}


After three years of work in close consultation with case study stakeholders, a standard questionnaire approach was adopted to allow the stakeholders to feed back their experiences of the operationalisation of the ES concept conducted in their case study. The questionnaire protocol (Supplementary Material 2) was designed to be adaptable, appropriate and sensitive to local case study conditions, and to allow assessment of the operationalisation of the ES concept across a range of contexts, including different land-use and ecosystem management issues. To avoid biases in the answers, the following principles were adhered to: (i) the list of individuals selected to complete the standard questionnaire must be agreed with the local stakeholder representatives (CABs), which controlled for biases in the selection of participating respondents; and (ii) questionnaires were presented in a way that strived for independence from the research team and allowed for free and frank completion of the questionnaire by the respondents. Survey implementation teams were used in each case study, who were responsible for the delivery of a standard questionnaire, collection of the responses and delivery of the data to the core analysis team. These implementation teams and core analysis teams were independent of the case study research teams (for full details see Supplementary Material 2). Furthermore the protocol required that questionnaires be completed anonymously, but the respondents could choose if they wished to declare their identity.

\begin{tabular}{|l|c|c|}
\hline Question & $\#$ & F \\
\hline Self-characterisation of users & & \\
\hline 1. The level of participation of the respondent in the project & 6 & A \\
\hline 2. The interest that the respondent has in the study area & 6 & A \\
\hline 3. The role of the respondent in relation to the addressed problem & 5 & A \\
\hline 4. The allegiances to social groups in the study area & 10 & A \\
\hline The perception of the participatory process & & \\
\hline 5. How the respondent experienced the cooperative process within the project & 6 & A \\
\hline 6. How well the process was organised & 5 & A \\
\hline The perceived impact & & \\
\hline 7. The impact of the project on their personal perception & 5 & B \\
\hline 8. The impact of the project on the study area & 5 & B \\
\hline 9. The main practical advantages of the work conducted & 1 & C \\
\hline 10. The main practical limitations of the work conducted & 1 & C \\
\hline The practical usefulness of the methodsitools & & \\
\hline 11. Aspects of the methodttool used & 10 & B \\
\hline 12. Overall usefulness of the methoditool & 2 & D \\
\hline
\end{tabular}

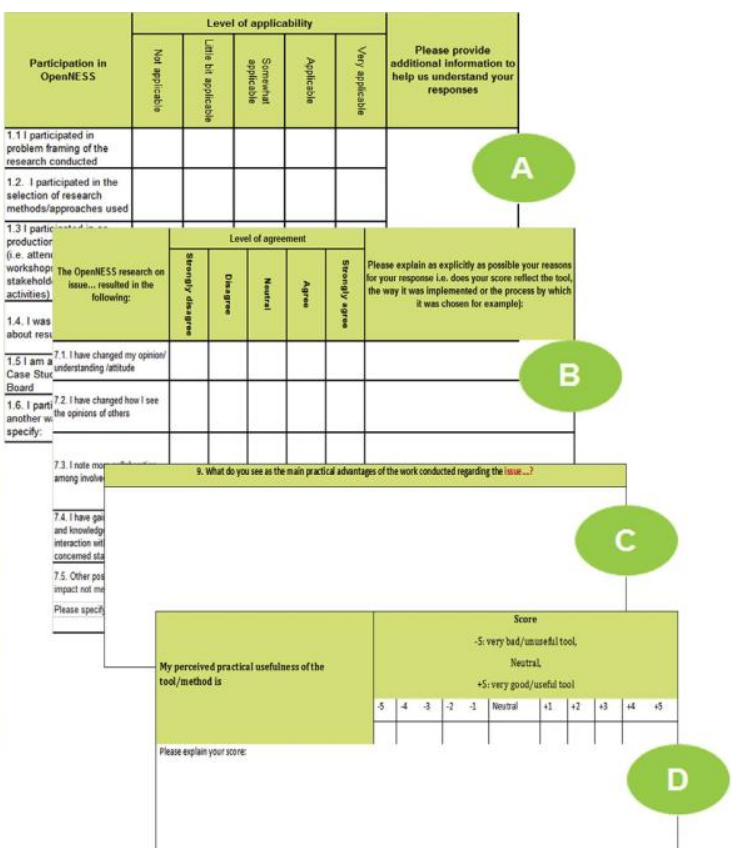

Fig. 2. Structure of standard questionnaire with four topics, 12 themes, 63 statements (\#) and 4 question formats (F), examples of which are shown and labelled A-D (see Supplementary Material 2 for full questionnaire).

Three main approaches were used for selecting respondents: (i) restricting the respondents to $\mathrm{CAB}$ members (eight case studies), (ii) complementing all $\mathrm{CAB}$ members with stakeholders outside the $\mathrm{CAB}$ (eight case studies), and (iii) stakeholders, but not all CAB members (11 case studies). As the questionnaires were completed anonymously no demographics of the stakeholders can be provided. Rather their role in the case study was captured in the questionnaire. 


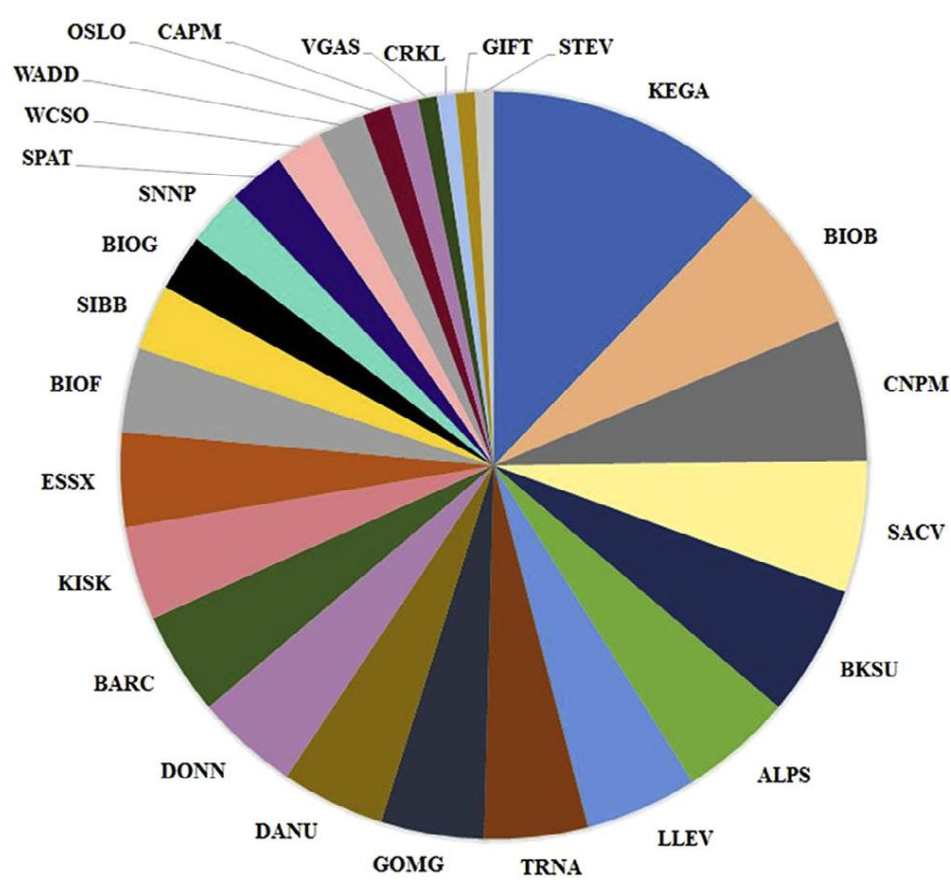

Fig. 3. Proportion of total responses, to an anonymous questionnaire completed by stakeholders reporting the practical advantages and limitations of the ES concept, from each of 27 case studies $(n=246)$. Case study codes explained fully in Supplementary Material 1.

The questionnaire was structured to cover four topics, and consisted of 12 themes, which each contained a number of statements. The four main topics were (i) self-characterisation of users, (ii) perception of the participatory process followed in the case study, (iii) perceived impact, and (iv) practical usefulness of tool(s) (Fig. 2). There were four question formats: a set of statements with a 5 point ordinal scale and a single associated open question for all the statements (format A, Fig. 2); a set of statements with a 5 point ordinal scale and an associated open question for each statement to allow fuller reporting (format B, Fig. 2); open questions (format C, Fig. 2); and finally a question where respondents were asked to rate their opinion of the overall usefulness of the method/tool on an 11 point ordinal scale ranging from -5 to +5 and an associated open-ended question (format D, Fig. 2). The formatting of the questions was structured following consultation and strived to provide stakeholders with a sufficient range to fully express their opinion. The evaluation of the tools which used an 11 point scale will be considered in another publication.

When the questionnaires were presented to stakeholders, the majority of the case studies (22 out 27) provided the respondents with detailed summary information on the tools and methods applied in the case study and the results obtained. The methods used to deliver this information are listed in Table 2. The content of the background information documents focused mainly on the applied tools and methods ( 21 case studies) and on the results (22 case studies). $\mathrm{CAB}$ members also had an opportunity to ask questions related to the presented information. Half of the cases also provided basic information about the OpenNESS project. The majority of the cases ( 23 cases) provided the background information in their national language, resulting in the use of 15 languages: Bengali, Catalan, Dutch/Flemish, English, 
Finnish, French, German, Hungarian, Italian, Norwegian, Portuguese, Romanian, Slovak, Spanish, and Swahili.

Table 2. Delivery mechanisms of information/questionnaires and forms of information provided by the case studies $(n=27)$ to their respondents prior to completion of the evaluation questionnaire.

\begin{tabular}{lllllll}
\hline & \multicolumn{3}{l}{$\begin{array}{l}\text { Delivery mechanism of } \\
\text { questionnaire/information }\end{array}$} & \multicolumn{2}{l}{ Forms of information provided to respondents } \\
& $\begin{array}{l}\text { E-mail in } \\
\text { advance }\end{array}$ & $\begin{array}{l}\text { Printed At a } \\
\text { copy }\end{array}$ & $\begin{array}{l}\text { At meeting } \\
\text { mowerPoint }\end{array}$ & $\begin{array}{l}\text { Fact-sheet or } \\
\text { slides }\end{array}$ & $\begin{array}{l}\text { Academic } \\
\text { papers/long } \\
\text { documents }\end{array}$ \\
\hline $\begin{array}{l}\text { Number of CSs } \\
\text { employing this method }\end{array}$ & 15 & 7 & 17 & 16 & 14 & 4 \\
\hline
\end{tabular}

\subsection{Number of responses}

Some case studies investigated multiple issues during the lifetime of the project; these were termed sub-projects. For five case studies these sub-projects were assessed separately by the stakeholders in the questionnaires. In three case studies the same individuals answered the questionnaire for each of the separate subprojects, while for two case studies, which each had three subprojects, different people were recommended by the CAB to complete the questionnaire for each sub-project. When multiple questionnaires were received from an individual concerning different sub-projects, they were treated as discrete responses for the subsequent analysis. In total 230 people evaluated 36 projects/subprojects and returned 246 questionnaires; 239 fully completed questionnaires were received from 25 case studies and included in the statistical analysis (case studies GIFT and WADD did not complete Q5 or Q6).

The number of questionnaires returned varied between case studies (Fig. 3), reflecting the collaboration mode and the method of implementing the standard questionnaire. Some case studies that interacted with a wide range of stakeholders delivered over 10 questionnaires while those that primarily interacted with a few decision makers returned fewer than five questionnaires. The return rate varied depending on the delivery method applied in the case study (Supplementary Material 3). The lowest response rates were in case studies with e-mail questionnaire delivery, whereas the highest response rates resulted from questionnaire delivery at meetings/workshops. For example, the Kenya case study (KEGA) conducted a stakeholder workshop and 30 people completed the questionnaire.

\subsection{Analysis of responses}

The practitioners' open-ended answers to questions on the practical advantages and limitations of the work conducted (Q9 and Q10) were analysed by two core writing teams. First, the lead group member in each team read all responses and derived categories of 
advantages and limitations of the ES concept that were identified in the responses; the whole team then iteratively coded each response according to the identified categories. Each response could be coded into multiple categories, as some statements mentioned multiple advantages and/or limitations. Secondly, the leader of each team checked and revised the coding and categories of both advantages and limitations, which resulted in some changes that were iterated across the team members, until an agreement was reached.

Table 3. Percentage of stakeholder responses in each category of the 5 point scale, in response to statements about their involvement in the case study project ( $1=$ not applicable and 5 = very applicable).

\begin{tabular}{llllll}
\hline Themes + statements & \multicolumn{5}{l}{ Scale of applicability } \\
\hline 1. Level of participation & $\mathbf{1}$ & $\mathbf{2}$ & $\mathbf{3}$ & $\mathbf{4}$ & $\mathbf{5}$ \\
In problem framing & 42 & 10 & 9 & 19 & 21 \\
In selection tools & 48 & 13 & 11 & 19 & 9 \\
In co-production of knowledge & 18 & 8 & 8 & 30 & 36 \\
I was fully informed of results & 8 & 3 & 10 & 36 & 43 \\
Member of Case Study Advisory Board & 37 & 6 & 3 & 15 & 39 \\
& & & & & \\
2. Level of personal involvement & 31 & 3 & 4 & 13 & 50 \\
Live in area & 48 & 9 & 6 & 16 & 22 \\
Economically dependent on land/water & & & & & \\
based activities & 56 & 8 & 8 & 14 & 14 \\
Economically dependent on non-land/ & & & & & \\
water activities & 50 & 3 & 3 & 14 & 30 \\
Own land in the area & 26 & 8 & 14 & 18 & 35 \\
Use area for leisure & & & & & \\
& & & & & \\
3. Role in the area & 32 & 9 & 14 & 23 & 22 \\
Make decisions related to issue studied & 16 & 11 & 14 & 33 & 27 \\
Contribute to decision-making & 14 & 9 & 19 & 27 & 31 \\
Affected by issue studied & 2 & 1 & 4 & 29 & 64 \\
Interested in issue investigated & & & & & \\
\hline
\end{tabular}

The responses to the two blocks of process questions (Q5 and Q6) were not completed by two case studies (i) Planning with Green Infrastructure in five linked cases, the Netherlands (GIFT) and Ecosystem services in coastal management, Wadden Sea, the Netherlands (WADD), as the research processes involved in these case studies did not involve a CAB. They were therefore considered too different to be included in the analysis of these questions or in the stepwise linear regression analysis.

To determine whether, and how much the likelihood of a 'change in action' (addressed by one single question and considered the endpoint of an ES study) was influenced by the numeric responses to questions on self-characterisation, the research process, and perceptions of the impact of the research, an auto-stepwise regression analysis was carried out. This statistical technique was used because of the high correlation between questions (Supplementary Material 4), and provided a means of determining the aspects which most influenced stakeholder perspectives on the likelihood of a 'change in action' in the case studies. Statistical analysis was performed using the statistical software package Genstat 16th 
Edition (VSN International 2013). The analysis was conducted centrally and not influenced by the research case study leaders.

\section{Results}

\subsection{Characterisation and role of the respondents}

The involvement of the respondent in the case study research was evaluated through questions on $\mathrm{CAB}-m e m b e r s h i p$ and engagement in research formulation and knowledge sharing (Table 3). Around half of responses indicated they were members of the CAB, whilst over a third reported they were not members, and the remaining responses indicated some involvement with the $\mathrm{CAB}$. This may reflect, in part, the dynamic nature of $\mathrm{CAB}$ membership with individuals leaving, and new members joining during the lifetime of the project in some case studies.

Although almost $40 \%$ of responses indicated involvement in framing the issue, only $28 \%$ considered that they had been involved in the selection of the tools (Table 3). Overall, two thirds of the responses reported contributing to the production of knowledge by attending workshops and other stakeholder engagement activities. Most considered they had been fully informed about the results of the research, but $20 \%$ indicated they had not been fully informed. The open-ended responses of those who considered they had not been fully informed of the results revealed that they felt they had not been informed about all aspects of the project as they were only active on a limited part of the case study. For example respondents wrote 'I only took part in a QuickScan workshop of honey'. This highlights that the use of the ecosystem service concept in practice often involves many stakeholders working in different areas of assessment and over different time spans.

As regards personal connection to the area two thirds of the responses indicated personal/professional involvement in the geographical area of the case study. Overall $63 \%$ scored the statement 'I permanently live in the area' as applicable or very applicable. The open-ended answers indicated that those who were not closely involved in the area were very precise about the actual geographical location of the study area when answering this question. For example some wrote 'I live there but not in the case study area'.

Overall, $38 \%$ of responses reported economic dependence on a land/water based activity in the area while $28 \%$ reported economic dependence that was not land/water based. A cross tabulation of economic dependence on land/water and non-land/water based activities revealed that $11 \%$ of responses indicated economic dependence on both land/water based activity and non-land/water based activity in the area. Respondents in this group were often involved in tourism, for example 'We operate four selfcatering cottages' or they were engaged in farming plus another activity e.g. 'I have many entrepreneurships around. I have bees and a small farm and I do other things as well'. In contrast, 33\% of responses reported they are not economically dependent on either a land/water or a non-land/water based activity in the case study area. The open-ended answers revealed that many of the respondents were 
planners and managers who may be responsible for a larger area than the case study, and therefore considered that they were not economically dependent on just the case study area. The open-ended answers also revealed that some respondents were researchers associated with the area but not part of the funded research team: 'I have scientific interest in the area'; 'My interests are related to research on biotic components in aquatic ecosystems'. There were also individuals in this group who indicated they were volunteers receiving no economic reward e.g. 'I am also a Volunteer Park Ranger for High Woods Country Park'.

There is evidence that some respondents were unsure how to score these two economic questions if they were employed by a government agency engaged in management of a land/water based activity. Some scored both these questions as not applicable, e.g. 'I am forest staff, I am an employee of Kenya Forest Service (KFS)', while others scored such situations as very applicable (i.e. '5'), e.g. 'I am a professional studying forest sciences'.

The characterisation of the respondents, revealed that nearly half made decisions related to the issue studied in the case study, while $23 \%$ considered they had some degree of decisionmaking power and the rest answered that they had none. However when asked if they contributed to decision-making related to the issue investigated, $85 \%$ of responses indicated some level of contribution. A majority of responses considered that they were affected by the issues investigated in the case studies to some degree, with only $14 \%$ stating that they were unaffected by the issues. Similarly, $93 \%$ of responses reported that they were interested in the issue investigated in the case study to some degree, which is not unexpected, as the majority of respondents were either members of the $\mathrm{CAB}$, or had attended workshops or meetings.

\subsection{Analysis of the process conducted to co-produce knowledge}

Most respondents thought that the process was well organised in the case study (Fig. 4). In general, most responses $(>80 \%)$ agreed with the statements that, 'the process was transparent', 'the people involved were trusted', 'the process was inclusive' and 'there was good facilitation'. One aspect with a relatively high level of dissent was for the statement 'All the relevant stakeholders were represented'. Analysis of the comments associated with this statement indicated that respondents recognised that not all stakeholders can be consulted, for example 'It would be impossible to consult all, everyone has their own opinion'; 'it was a small workshop, many of the key players were present but they could not represent all interests'. One respondent suggested that a group was represented by the wrong people: 'Some entities were not present in some relevant steps of the project or were represented by technicians with no decision-making capacity'. However it was suggested that sometimes the lack of representation was not the fault of the project, e.g. 'The problem is that the relevant stakeholders often do not have time to get involved in these processes (reachability of the stakeholders)'.

Most of the replies (86\%) indicated that the respondents were satisfied with the facilitation during the stakeholder meetings or workshops and during the stakeholder process in general 
e.g. 'The workshop process was perfectly clear and I felt everyone was given the opportunity to fully participate'.



Fig. 4. Agreement or disagreement of 246 stakeholders to statements related to the process used in the case studies. Where the number of responses for a given answer was more than $5 \%$ the value is shown on the graph. Responses on a 5 point ordinal scale: $(1=$ strongly disagree, $2=$ disagree, $3=$ neutral, $4=$ agree and $5=$ strongly agree).



Fig. 5. Agreement or disagreement of 246 stakeholders to statements related to changes in their personal views and knowledge. Where the number of responses for a given answer was more than $5 \%$ the value is shown on the graph. Responses on a 5 point ordinal scale: $(1=$ strongly disagree, 2 = disagree, $3=$ neutral, $4=$ agree and $5=$ strongly agree).

In order to increase the (potential) impact of the assessments in terms of practical implementation, the involvement of stakeholders with a clear mandate is also important (i.e. to do these assessments, to negotiate with other stakeholders during decision-making, and to implement things afterwards). Therefore, participants were asked if they felt that the organisations involved had a mandate to address the issues, and $69 \%$ of the responses were positive. 


\subsection{Analysis of the expected impact of the research conducted in the case study}

The respondents reported that ES research had generated change in their case study. A majority of responses $(91 \%)$ reported that they gained new insights and knowledge through their interaction with researchers and concerned stakeholders (Fig. 5). Approximately two thirds considered they had changed their understanding and noted more collaboration among involved stakeholders. Fewer respondents reported they had changed how they see the opinions of others ( $41 \%$ agree).

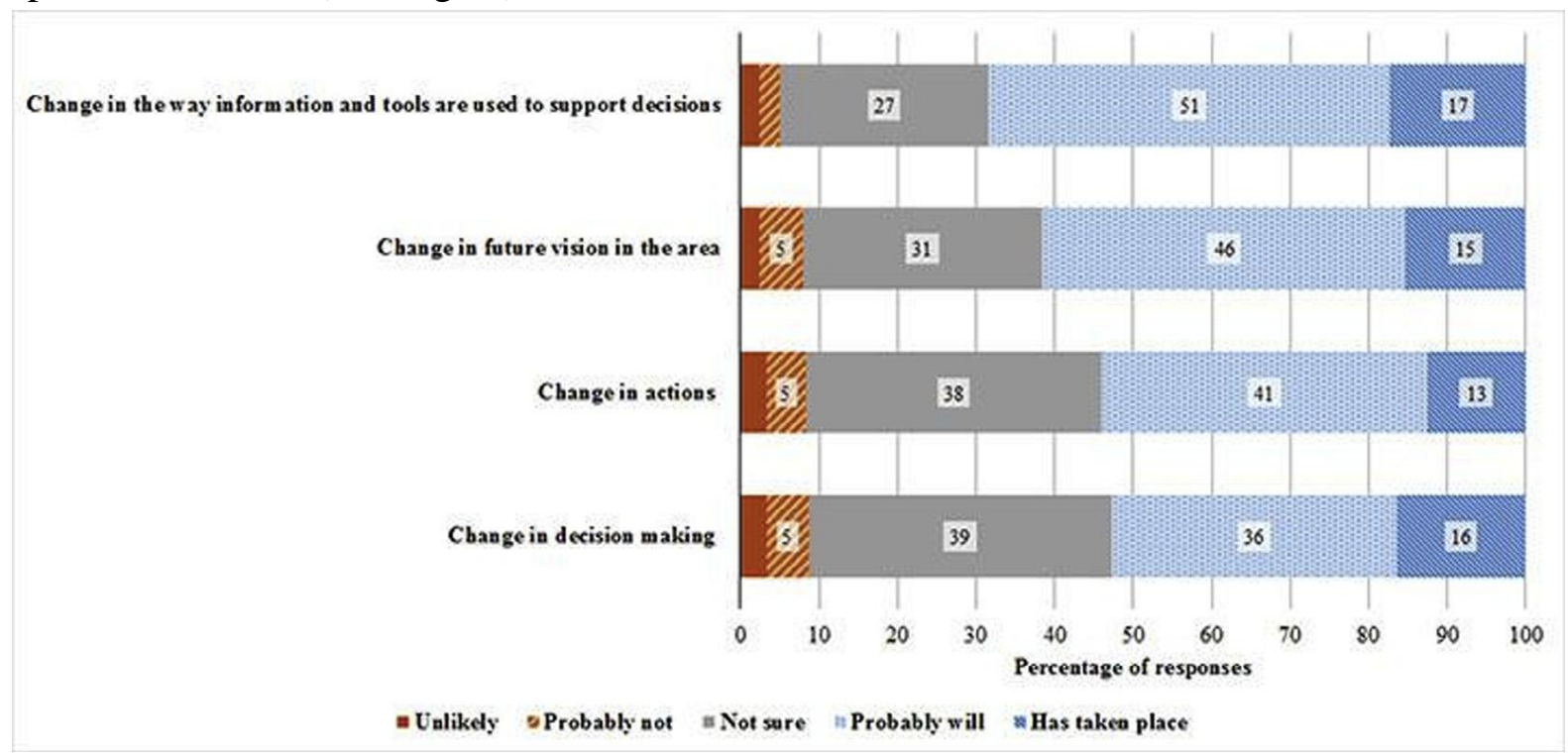

Fig. 6. Responses of 246 stakeholders to statements related to the intended or realised use of the ES research conducted in each case study. Where the number of responses for a given answer was more than $5 \%$ the value is shown on the graph. Responses on a 5 point ordinal scale: $(1=$ It is very unlikely, $2=$ Probably not take place, $3=$ Not sure, $4=$ Probably will take place and $5=$ Already took place).

A majority of responses (61\%) considered that the ES research will result in a change in the future vision of the area (Fig. 6), while some said it had already happened (15\%). The accompanying open-ended responses revealed that this result was often not within the power of the participants but with the decision-makers, e.g. 'The usage of the methods and research results very much depends on the persons doing the planning and decision-making', or that the time frame of the project was too short, e.g. 'Time too short to be policy relevant'. However, many were hopeful and wished for a change to happen as a result of the research, for example 'I hope so, as it should have raised awareness of spatial issues \& trade-offs'. The uncertainty is reflected in $31 \%$ of stakeholders scoring that they were 'not sure', for example 'It's difficult to say in this phase'.

A majority of respondents reported that it was likely that the ES research conducted in the case studies will result in a change in the way information and tools are used to support decisions (68\%). Although only $13 \%$ of responses reported that the ES research had already resulted in a change in actions, $40 \%$ considered that it was likely to happen, with an almost equal proportion being unsure. In general the comments suggest the respondents are not yet 
sure about the impact, but see potential and are hopeful, Approximately a third of the responses considered that the research will result in a change in decision-making $(36 \%)$ or indicated that this has already happened (16\%). However, over a third (39\%) reported they were 'not sure'. Participants noted that the ES concept can influence decision-making, but in many cases considered it was too early to tell when completing the questionnaires. They think that scientific information resulting from ES research can be used as arguments and contribute to planning and decision-making. In some cases additional testing or efforts are needed before this can be realized.

Table 4. Categories identified from the practitioners' responses to the open-ended questions on the practical advantages of the work conducted in the case study ( $\mathrm{n}=246$ responses across 27 case studies).

\begin{tabular}{|c|c|c|}
\hline Category & $\begin{array}{l}\text { Number of } \\
\text { statements }\end{array}$ & Description of category \\
\hline Awareness, language, concept & 57 & $\begin{array}{l}\text { Personal experience of improved awareness or a deeper conceptual understanding as well as awareness- } \\
\text { raising among stakeholders more broadly. This was the most frequently identified benefit }\end{array}$ \\
\hline Information or data & 45 & $\begin{array}{l}\text { New information or data, sometimes with an expectation that it would be used, and at other times a } \\
\text { specific use was mentioned. Some mentioned simply that the project produced information, e.g.: } \\
\text { 'gathered and developed important information and data on the case study area that can be useful for further } \\
\text { research' }\end{array}$ \\
\hline $\begin{array}{l}\text { Input to an existing decision-making } \\
\text { process or management system }\end{array}$ & 43 & $\begin{array}{l}\text { Input to already existing decision-making processes or systems, sometimes also anticipated input: 'The } \\
\text { application in land-use planning and other strategic documents'; 'The project will be the basis for better } \\
\text { legislative integration of ES'; 'Detailed ES analysis developed, which could be used for land-use planning' }\end{array}$ \\
\hline Science-based methods, scientific support & 41 & $\begin{array}{l}\text { Scientific evidence or academic approach, sometimes mentions of ways in which the scientific basis } \\
\text { would support decision-making: 'It has provided arguments and scientific elements'; 'It provided an external } \\
\text { stamp of academic approval to our work'; 'Method development of planning. Induding the scientific methods' }\end{array}$ \\
\hline $\begin{array}{l}\text { Ecosystem service evaluation and } \\
\text { valuation }\end{array}$ & 33 & $\begin{array}{l}\text { Supports identifying and comparing values: 'Gives a wider overview of present value of areas; facilitates } \\
\text { people to make trade-offs'; 'Valuing the ecosystem services in euros makes comparisons between apples and } \\
\text { pears easier' }\end{array}$ \\
\hline GIS/Land-use planning tools & 33 & $\begin{array}{l}\text { Spatial, geographical, territorial analysis and its anticipated benefits or identified support to land-use } \\
\text { planning: 'Useful research - place based, site specific information on where people go for land based activity'; } \\
\text { 'Better planning and management in the landscape'; 'Modelling + mapping is an important tool for achieving } \\
\text { consensus and for framing discussions' }\end{array}$ \\
\hline Engagement, participation & 26 & $\begin{array}{l}\text { Facilitated dialogue, hearing stakeholder views; authorities or researchers inviting other actors to } \\
\text { participate: 'It is helpful to involve people'; 'Improves interaction and participation'; 'facilitation of } \\
\text { dialogue...' }\end{array}$ \\
\hline Comprehensiveness, broadness & 25 & $\begin{array}{l}\text { Comprehensive or broad treatment of ecosystem services; new ways of identifying more ecosystem } \\
\text { services: 'Gives wider overview of present value of ecosystem services'; 'A comprehensive look at the landscape } \\
\text { in terms of its protection and utilization' }\end{array}$ \\
\hline Communication across interests & 25 & $\begin{array}{l}\text { Distinct or opposing views discussed and communicated, sometimes named specifically, e.g. agriculture } \\
\text { and environmental interests: 'it promoted a positive interaction and discussion among different stakeholders } \\
\text { that usually do not communicate', 'unification of different stakeholders'; 'New positive dynamics between } \\
\text { stakeholders to realize the vision' }\end{array}$ \\
\hline Collaboration & 16 & $\begin{array}{l}\text { Co-operation within the project or new collaboration opportunities across stakeholders: 'The cooperation } \\
\text { of various stakeholders'; 'Learn how to collaborate, different type of people had to work together' }\end{array}$ \\
\hline $\begin{array}{l}\text { Communication across administrative } \\
\text { sectors }\end{array}$ & 15 & $\begin{array}{l}\text { Communicating with different sector representatives and different administration units as well as related } \\
\text { learning about other views and discussing to find consensus or an agreement: } 4 . ., \text { good to integrate in } \\
\text { planning for forest management'; 'regionality, cooperation, and sufficient communication' }\end{array}$ \\
\hline
\end{tabular}

\subsection{Analysis of the open-ended answers on advantages and limitations}

In total, 246 responses to the open-ended question on the main practical advantages of the work conducted in the case study were received. Some responses mentioned advantages that respondents had already experienced, while others indicated they expected certain advantages to eventuate. Some responses were personal, indicating learning or improved awareness; some referred to a project or decision-making process likely associated with the case study; and others referred mainly to the case study itself. Certain issues were mentioned multiple times, and we consider these to represent themes or categories of advantages. All responses were coded according to these categories. 
The responses identified with 11 advantage groups (Table 4) related to: increased awareness and information; communication, participation and collaboration; comprehensive and science-based knowledge production; spatial knowledge and its input to planning; and decision and management system support.

Table 5. Clusters of categories identified from the practitioners' responses to the open-ended questions on the practical limitations of the work conducted in the case study.

\begin{tabular}{|c|c|c|}
\hline Cluster & $\begin{array}{l}\text { Number of } \\
\text { statements }\end{array}$ & Description of cluster \\
\hline $\begin{array}{l}\text { Limitations linked to implementation of } \\
\text { results/working context }\end{array}$ & 155 & $\begin{array}{l}\text { Limitations in the implementation of the ES concept was perceived by respondents as crucial. It was driven } \\
\text { by: lack of time, finances or interest; current legislation or decision-making settings. The most important } \\
\text { limitation reported was a problem in transfer of knowledge/low awareness, which resulted in difficulty in } \\
\text { transferring information to the wider public (e.g. land users): 'the replicability of the work is very much } \\
\text { affected / conditioned by the availability of stakeholders' } \\
\text { Similar limitations emerged when existing decision-making or territorial planning institutions were not } \\
\text { harmonised with implementation of the ES concept: 'limitation in looking to achieve all social spheres, } \\
\text { according to their needs and interests' } \\
\text { Lack of interest, especially among land owners, decision-makers or some other stakeholders, was also noted } \\
\text { as a practical limitation: 'ignorance of competent authorities resulting from the lack of interest and insufficient } \\
\text { information flow' }\end{array}$ \\
\hline Limitations in methodology & 74 & $\begin{array}{l}\text { Respondents reported certain limitations of the method used or in its implementation, or found ES } \\
\text { valuation difficult in general. Some comments were specific and related to particular processes performed } \\
\text { or methods applied in the case study, while other comments were more general: 'not enough time to deepen } \\
\text { the analysis on some methods' }\end{array}$ \\
\hline Limitations with data & 18 & $\begin{array}{l}\text { Data availability was specifically mentioned as an issue, indicating data is not always available, especially } \\
\text { for ES valuation: 'Data limitations - availability, format, cost of including, processing etc.' }\end{array}$ \\
\hline Other limitations & 9 & $\begin{array}{l}\text { Other problems related to case study specific issues, which were not directly connected to the ES concept: } \\
\text { 'the protection scheme that the winery sector formed...' }\end{array}$ \\
\hline
\end{tabular}

Many of the identified advantages were reported factually, just naming the advantage, e.g. 'communicational connection'. At other times the sentence included a statement that reported an experience of the advantage, e.g., 'It provided an external stamp of academic approval...', and some other responses anticipated or expected the advantages to materialize, saying 'could', 'would', 'is important' or 'is good'.

Table 6. Accumulated analysis of variance from a stepwise regression following ten iterations. Significant terms appear in bold.

\begin{tabular}{|c|c|c|c|c|}
\hline & Degrees of Freedom & Mean square & Variance ratio & F pr. \\
\hline Change in decision-making & 1 & 74.951 & 247.12 & $<0.001$ \\
\hline All the relevant stakeholders were represented & 1 & 3.8773 & 12.78 & $<0.001$ \\
\hline I have changed my understanding & 1 & 1.6446 & 5.42 & 0.021 \\
\hline The process was inclusive and provided opportunities to get involved & 1 & 1.2776 & 4.21 & 0.042 \\
\hline Change in the way information and tools are used to support decisions & 1 & 1.3011 & 4.29 & 0.04 \\
\hline OpenNESS Case Study & 1 & 1.1808 & 3.89 & 0.05 \\
\hline I participated in problem framing of the research conducted & 1 & 1.0827 & 3.57 & 0.061 \\
\hline I note more collaboration amongst involved stakeholders & 1 & 0.8608 & 2.84 & 0.094 \\
\hline I participated in the selection of research method/approaches used & 1 & 0.8257 & 2.72 & 0.101 \\
\hline The role of all people involved were clear & 1 & 0.6692 & 2.21 & 0.139 \\
\hline Residual & 165 & 0.3033 & & \\
\hline
\end{tabular}

Fewer respondents answered the open-ended question on the main practical limitations of the work conducted in the case study. In total 186 responses were analysed (i.e. in a quarter of the returned questionnaires this question was left blank). In addition to these blank boxes, in twelve responses no limitations were specified, i.e. the respondents simply acknowledged the process of the project implementation and the results achieved. Categorisation of the 256 statements revealed 13 categories (See Supplementary Material 5), with 'shortages in method used or its application' being the most commonly mentioned limitation (61 mentions). 
The 13 categories can usefully be clustered into four groups: limitations linked to implementation of results, limitations in methodology, data limitations, and case-studyrelated limitations (Table 5). Most of the statements from the responses related to limitations linked to implementation of results.

As indicated above, the responses varied in their identification of the limitations: some reported detailed comments on the implementation of the ES concept in the case study (e.g. comments on the particular model used), while others commented very generally (e.g. on the difficulty of ES valuation). Comments within the same case study were sometimes similar, i.e. they related to a particular category, which indicates that the main goal specified in a particular case study had a large impact on the limitations perceived by the respondents.

\subsection{Factors associated with a reported 'change in action'}

The stepwise regression analysis involving all factors found that, from the full dataset of 31questions, only six were significantly associated with the respondents' score for the question 'The OpenNESS research resulted in a change in actions' $(61 \%$ of the variance accounted for by the model).

The stepwise regression (Table 6) revealed significant associations with the factor 'OpenNESS Case Study' and the responses to the statements (i) 'Change in decision-making' (ii) 'All the relevant stakeholders were represented' (iii) 'I have changed my understanding' (iv) 'The process was inclusive and provided opportunities to get involved' and (v) 'Change in the way information and tools are used to support decisions'. All associations were positive. The term 'OpenNESS Case study' was the least significant term in the model indicating commonality between case studies. These five questions were good predictors of a change in action in the case studies. However, with the high correlation between questions, the selection of one question does not mean the other correlated questions are unimportant. For example, while the response to the questions 'All the relevant stakeholders were represented' was fitted in the model, the high correlation with the other four questions in that block ('There was a high level of interaction among the represented stakeholders'; 'The process was transparent'; 'The organisations involved had a mandate to address the issues'; 'I trust the people involved') meant that this group of questions were also associated with a 'change in action'. Similarly responses to the question 'The OpenNESS research resulted in a change in decision-making' accounted for the most variance in the fitted model but it was also highly correlated with other questions. While dropping this term from the model reduced the overall model fit, it did not significantly change the factors in the analysis. The model presented in Table 6 includes the factors which collectively accounted for maximum variance.

\section{Discussion}


The results of this study have shown that the ES concept was operationalised in the 27 case studies, and consequently supports the generally held expectation that the ES concept helps practitioners address their specific real-world management needs.

In this study we specifically enquired if a 'change in action' had occurred as a result of the ES research, and around half the responses identified that a change in action had occurred or was likely to occur. The ES research conducted and 'change in action' reported encompassed all three decisions types proposed by McKenzie et al. (2014) and Waylen and Young (2014) namely (i) conceptual, i.e. to raise awareness and reframe dialogue; (ii) instrumental, to make specific decisions; and (iii) strategic, to build support for plans or policies. For example the Italian case study (GOMG) is an example of conceptual use. The work in the Italian case study showed the added value of building an artificial wetlands from different perspectives (technical, ecological, recreational). The respondents reported that there had been a change in the future vision in the area i.e. a reframing of the dialogue locally. Water and planning managers also reported they will use the results when updating the river basin management plan, and they asked to work with the research team again to develop other similar case studies. The work conducted in Brazil (BIOB) on a payment for ecosystem service scheme has been included in the Directive Plan for the area, and is contributing to a change of legislation i.e. an example of instrumental and strategic use of the ES research. While in the northern Scottish case study (CNPM), the work was used strategically to help lever funding for development projects ( $\$ 3.6 \mathrm{~m}$ from the UK National Heritage Lottery Fund). A map showing the integrated valuation of recreational use of the area was used as evidence to support the development of walking trails. We do not claim that the proposal for funding was successful solely as a result of the ES assessment, but CAB members reported that they considered the work, which highlighted collaborative working and participatory planning, had certainly helped to convince the awarding committee to approve the funds (Tomintoul and Glenlivet landscape partnership, 2016). The decision context of all 27 case studies is reported in Barton et al. (2018). They found, in their analysis of this same set of case studies, that the majority of appraisals conducted were for informative purposes and significantly fewer had a decisive or technical policy design focus. As the case studies were conducted in real world situations it was noted that sometimes the stakeholders insisted that the assessment should not be conducted with a real decisive endpoint (e.g. Dick et al., 2017). Analysis of the knowledge needs expressed by the stakeholders and the temporal shift in conceptual understanding of the researchers are explored in Carmen et al. 2018 and Potchin et al., 2018.

Change in action, takes time, and even in the case of CNPM where the ES work was used to successfully lever development funds, the majority of respondents completing the questionnaire only scored this activity as 'likely to happen' (as the application for funding had not been submitted at the time of questionnaire completion). This temporal mismatch between the evaluation of the ES concept in this study and the final delivery was echoed in many case studies, when respondents indicated that it was too early to tell if the work would result in a change in action, but indicated that they thought it likely. Also many statements about advantages echoed an anticipation for future improvements. The need to monitor such changes over time has been highlighted in the literature (Carpenter et al., 2012; Posner et al., 
2016), leading Maass et al. (2016) to recommend the long-term social-ecological research platform approach (Haberl et al., 2006) in order to follow ES decision-making.

A 'change in action' resulting from ES research also requires a change in decision making (identified as the most important factor in the step-wise regression). The lack of political will, and the current governance structures were mentioned as limitations to the operationalisation of the ES concept in the open-questions. These limitations were identified in the urban Slovak case study (TRNA), based on a review (Bezák et al., 2017) of national and local policy and planning documents and stakeholder feedback. They report a certain resistance of the decision-makers to change their accustomed routine planning procedures, which are grounded in sectoral planning and lack accredited ES assessment methodologies and communication strategies to raise awareness of the ES concept.

Analysis of the questionnaires from the 27 case studies revealed that the most reported benefits that the ES research has provided relates to knowledge accumulation. However, almost as important are the directly applicable methods and tools that can connect science to the development and implementation of decisionmaking, management and planning. A third advantage of ES research identified by practitioners is one of bridging and communicating which advances collaboration and engagement. These findings help to expand on the existing understanding of ES knowledge use. For example, the review of Martinez-Harms et al. (2015) evaluated the degree to which ES assessments have addressed management decisions, and found that less than half of the studies specified management alternatives and only $3 \%$ of the studies documented how the study has been used for decision-support. Furthermore with regards to ES valuation knowledge, Laurans et al. (2013) found that only a fraction of studies have analysed the use of knowledge.

Many of the methods and tools tested involved stakeholders directly, and as noted, stakeholder communication and collabora- tion were highlighted positively in the survey responses. The work conducted across the case studies follows a growing trend in the use and development of decision support tools, which have shifted towards participatory approaches in recent years (Carberry et al., 2002; Grizzetti et al., 2016a, Grizzetti et al., 2016b, MartínLópez et al., 2012; McCown and Parton, 2006; Nelson et al., 2002; Verweij et al., 2014). Central to participatory processes is the principle of actively involving stakeholders and their knowledge, instead of treating them as passive recipients of knowledge (Kloppenburg, 1991; Massey et al., 2006). The link between researchers and stakeholders has historically been patriarchal. In their review of urban ecosystem service assessments, Haase et al. (2014), found that only six of a total 217 papers (3\%) reported communicating the results of the study to stakeholders. Stakeholders are commonly involved in ES studies in three ways: (i) determining the planning relevance of the ES concept, (ii) developing frameworks and selection of relevant ES to assess, and (iii) collecting data and assessing ES (Haase et al., 2014). The approach adopted in the case studies reported here involved much closer working, with stakeholders co-designing the study in a place-based approach, and the results of the survey indicate that this was appreciated by the stakeholders. The researchers' views of the process of operationalisation were surveyed and reported in Saarikoski et al. (2018). They 
note that researchers also reported positively on the experience of co-design facilitated by the creation of Case Study Advisory Boards which they considered facilitated the uptake, utilization and influence of ecosystem service knowledge.

The ES research carried out in the case studies is an example of transdisciplinary science involving stakeholders, aiming to deliver salient, legitimate and credible science to the decision-making process (Lang et al., 2012; Röckmann et al., 2015). This link between science and decision-making is considered 'boundary work' (Gieryn 1983; Gieryn 1995; Guston 2001; Huutoniemi et al., 2010) at the interface between science and the real world, to help protect science from potential biases caused by what is at stake in decision-making. Communication and collaboration is crucial to forge the links between different interfaces and world views. Analysis of the open-ended questions in this study revealed that both awareness-raising and communication were key advantages of the operationalisation of the ES concept (Table 4). This confirms the potential of the ES concept to cross boundaries and to translate real-world problems into boundary research objects, thus further linking science with the real world (Lang et al., 2012).

The purpose of this study was to investigate the practical application of the ES concept across case studies that reflected a diverse range of different challenges, and to test the concept in a broad range of user-defined contexts making use of an evaluation by stakeholders. There have also been calls for a standardised scorecard approach in order to compare ES approaches across case studies and identify when the ES approach is most appropriate (Fürst et al., 2014), considering advantages and limitations. Our approach has been developed over three years of consultation with case study researchers and stakeholders and has resulted in parallel questions. The benefits identified by the survey respondents are similar to the criteria developed by Fürst et al. (2014): 'Shared knowledge base: integrating disciplinary knowledge', 'Building a shared vision', 'Social network and collaboration' (which they considered as advantages) and 'Requested knowledge basis and training, actor inequality', 'Supporting the detection of supply demand relationships', 'Involvement of socio-ecologicaleconomic system aspects in planning' (which they considered critical aspects). Fürst et al. tested their approach with researchers and found it suitable, but to date the views of stakeholders are unknown.

Stakeholders found the evaluation method in this study comprehensive, but time consuming to complete (one respondent reported it took $2 \mathrm{~h}$ although it commonly took 30-45 min). The correlation and step-wise regression analysis revealed that within blocks of questions there was much redundancy i.e. the answers to questions within a block were the same. This was especially true for the questions related to the evaluation of the process. Therefore, we would recommend keeping the structure of the blocks of questions but reduce the number of questions in each block. The mix of numerical and open questions was useful to cross-check the reasons for the scores and to aid understanding of the stakeholders views. There is some evidence that stakeholders also welcomed the mixed approach as it indicated a desire to fully understand their perspective. 
This study, conducted across 27 diverse case studies, found that the ES concept was broadly 'operational' and accommodated positivist, interpretivist and constructivist research strategies. The ES concept and participatory approaches applied in the different case studies opened a constructive dialogue among the different parties, supporting an important rationalisation of common problems. This exchange is pivotal in revealing the interdependencies between policy sectors, and spatial and land use planning at different levels according to the case study scale. In contrast, the natural capital concept, which is arguably more limited to monetary, accounting and valuation methods (positivist approaches) (e.g. Obst et al., 2016), was adopted by the CABs to a very limited extent in framing the research. Potentially the full 'community capitals' approach, which includes social, cultural, built, political, human and financial capital rather than focusing only on natural capital, may have resonated more with the CABs. The 'community capitals' approach can embrace positivist, interpretativist and constructivist methods (Fey et al., 2006).

Over the last century, human domination and modification of the planet has led scientists to refer to the current geological age as the 'Anthropocene' (Crutzen 2002), on account of the unparalleled intensity and magnitude of the role of humans in the changes affecting the Earth's ecological systems. Three changes are commonly advocated as required for transformational change on Earth: (i) change in the hearts and minds of individuals, (ii) change in human behaviours, and (iii) change in social institutions. The case studies show that the operationalisation of the ES concept in this study, which embedded the transdisciplinary approach, can indeed lead to each of these types of changes. The stakeholders reported new insights and knowledge (91\%), more collaboration (66\%), changed understanding $(65 \%)$, a change in the way information was used $(68 \%)$ which lead to a change in decision-making (53\%), and ultimately the probability of a change in action (54\%). The evidence for changes in social institutions was less obvious (Bezák et al., 2017) but is recognised to be a long term process. Stakeholders have reported that the ecosystem service concept can help address their specific real-world ecosystem management needs.

\section{Funding}

This research was funded by the European Union EU FP7 project OpenNESS (Grant agreement No. 308428).

\section{Acknowledgement}

This research was funded by the European Union EU FP7 project OpenNESS 'Operationalisation of Natural Capital and Ecosystem Services: From Concepts to Real-world Applications' (Grant agreement no. 308428). The OpenNESS project is solely responsible for the content of this publication. It does not represent the opinion of the European Union, nor is the European Union responsible for any use that might be made of information appearing herein. The goals of the project could not have been achieved without the active, willing participation of over 300 local stakeholders across all the case studies who although not acknowledged as authors, were pivotal to the work reported. The authors are indebted to them 
for sharing their knowledge, time and wisdom with us. The authors are also indebted to the two anonymous reviewers whose insightful comments improved the quality of this paper.

\section{Appendix A. Supplementary data}

Supplementary data associated with this article can be found, in the online version, at https://doi.org/10.1016/j.ecoser.2017.09.015.

\section{References}

Baró, F., Chaparro, L., Gómez-Baggethun, E., Langemeyer, J., Nowak, D., Terradas, J., 2014. Contribution of ecosystem services to air quality and climate change mitigation policies: the case of urban forests in Barcelona, Spain. Ambio 43 (4), 466-479. https://doi.org/10.1007/s13280-014-0507-x.

Baró, F., Palomo, I., Zulian, G., Vizcaino, P., Haase, D., Gómez-Baggethun, E., 2016. Mapping ecosystem service capacity, flow and demand for landscape and urban planning: a case study in the Barcelona metropolitan region. Land Use Policy 57, 405-417. https://doi.org/10.1016/j.landusepol.2016.06.006.

Barton, D.N., Kelemen, A., Braat, L., Gómez-Baggethun, E., Jacobs, S., Martín-López, B., Saarikoski, H., Termansen, M., Bela, G., Demeyer, R., García-Llorente, M., Hauck, J., Keune, H., Luque, S., Palomo, I., Pataki, G., Potschin, M., Schleyer, C., Tenerilli, P., Turkelboom, F., 2018. Dis) integrated valuation - assessing the information gaps in ecosystem service appraisals for governance support. Ecosyst. Serv. 29, 529-541.

Bezák, P., Mederly, P., Izakovičová, Z., Špulerová, J., Schleyer, Ch., 2017. Divergence and conflicts in landscape planning across spatial scales in Slovakia: opportunity for an ecosystem services approach? Int. J. Biodivers. Sci. Ecosyst. Serv. Manage. 13, 119-135. https://doi.org/10.1080/21513732.2017.1305992.

Bromham, L., Dinnage, R., Hua, X., 2016. Interdisciplinary research has consistently lower funding success. Nature 534, 684-687. https://doi.org/10.1038/nature18315.

Cairngorms National Park Authority. 2012. Cairngorms National Park Partnership Plan 20122017. Available at:

http://www.cairngorms.co.uk/resource/docs/publications/21062012/CNPA.Paper.1827.Cairn gorms\%20National\%20Park\%20Partnership\%20Plan\%202012-2017.pdf.

Carberry, P.S., Hochman, Z., McCown, R.L., Dalgliesh, N.P., Foale, M.A., Poulton, P.L., Hargreaves, J.N.G., Hargreaves, D.M.G., Cawthray, S., Hillcoat, N., Robertson, M.J., 2002. The FARMSCAPE approach to decision support: farmers', advisers', researchers' monitoring, simulation, communication and performance evaluation. Agr. Syst. 74, 141-177. https://doi.org/10.1016/S0308-521X(02)00025-2.

Carmen, E., Watt, A., Carvalho, L., Young, J., 2018. Knowledge needs for the operationalisation of the concept of ecosystem services. Ecosyst. Serv. 29, 441-451. 
Carpenter, S.R., Folke, C., Norström, A., Olsson, O., Schultz, L., Agarwal, B., Balvanera, P., Campbell, B., Castilla, J.C., Cramer, W., DeFries, R., Eyzaguirre, P., Hughes, T.P., Polasky, S., Sanusi, Z., Scholes, R., Spierenburg, M., 2012. Program on ecosystem change and society: an international research strategy for integrated social-ecological systems. Curr. Opin. Environ. Sustain. 4, 134-138. https://doi.org/10.1016/j.cosust.2012.01.001.

Clemente, P., Calvache, M., Antunes, P., Santos, R., 2015. Mapping stakeholders' perceptions on ecosystem services provision within Sudoeste Alentejano and Costa Vicentina Natural Park. VIII Congresso sobre Planeamento e Gestão das Zonas Costeiras dos Países de Expressão Portuguesa, Associação Portuguesa dos Recursos Hídricos, Aveiro.

Crutzen, P.J., 2002. Geology of mankind. Nature 415. https://doi.org/10.1038/415023a. 2323.

Díaz, S., Demissew, S., Carabias, J., Joly, C., Lonsdale, M., Ash, N., Larigauderie, A., Adhikari, J.R., Arico, S., Báldi, A., Bartuska, A., Baste, I.A., Bilgin, A., Brondizio, E., Chan, K.M.A., Figueroa, V.E., Duraiappah, A., Fischer, M., Hill, R., Koetz, T., Leadley, P., Lyver, P., Mace, G.M., Martin-Lopez, B., Okumura, M., Pacheco, D., Pascual, U., Pérez, E.S., Reyers, B., Roth, E., Saito, O., Scholes, R.J., Sharma, N., Tallis, H., Thaman, R., Watson, R., Yahara, T., Hamid, Z.A., Akosim, C., Al-Hafedh, Y., Allahverdiyev, R., Amankwah, E., Asah, S.T., Asfaw, Z., Bartus, G., Brooks, L.A., Caillaux, J., Dalle, G., Darnaedi, D., Driver, A., Erpul, G., Escobar-Eyzaguirre, P., Failler, P., Fouda, A.M.M., Fu, B., Gundimeda, H., Hashimoto, S., Homer, F., Lavorel, S., Lichtenstein, G., Mala, W.A., Mandivenyi, W., Matczak, P., Mbizvo, C., Mehrdadi, M., Metzger, J.P., Mikissa, J.B., Moller, H., Mooney, H.A., Mumby, P., Nagendra, H., Nesshover, C., Oteng-Yeboah, A.A., Pataki, G., Roué, M., Rubis, J., Schultz, M., Smith, P., Sumaila, R., Takeuchi, K., Thomas, S., Verma, M., YeoChang, Y., Zlatanova, D., 2015. The IPBES Conceptual Framework connecting nature and people. Curr. Opin. Environ. Sustainability 14, 1-16.

https://doi.org/10.1016/j.cosust.2014.11.002.

Dick, J., Andrews, C., Beaumont, D.A., Benham, S., Dodd, N., Pallett, D., Rose, R., Scott, T., Smith, R., Schäfer, S.M., Turner, A., Watson, H., 2016. Analysis of temporal change in delivery of ecosystem services over 20 years at long term monitoring sites of the UK Environmental Change Network. Ecol. Indic 68, 115-125.

https://doi.org/10.1016/j.ecolind.2016.02.021.

Dick, J., Verweij, P., Carmen, E., Rodela, R., Andrews, C., 2017. Testing the ecosystem service cascade framework and QUICKScan software tool in the context of land use planning in Glenlivet Estate Scotland. Int. J. Biodivers. Sci. Ecosyst. Serv. Manage. 13, 12-25. https://doi.org/10.1080/21513732.2016.1268648.

Dunford, R., et al., 2018. Integrating methods for ecosystem service assessment: Experiences from real world situations. Ecosyst. Serv. 29, 499-514.

EU FP7 OpenNESS Project. Wijnja, H., van Uden, G., Delbaere, B. (Eds.) 2016. Ecosystem services in operation: case studies. European Commission FP7. Available at: https://issuu.com/ecnc.org/docs/openness_casestudies_brochure.

Fey, S., Bregendahl, C., Flora, C., 2006. The measurement of community capitals through research. OJRRP 1 (1). https://doi.org/10.4148/ojrrp.v1i1.29. 
Fürst, C., Opdam, P., Inostroza, L., Luque, S., 2014. Evaluating the role of ecosystem services in participatory land use planning: proposing a balanced score card. Landsc. Ecol. 29, 1435-1446. https://doi.org/10.1007/s10980-014-0052-9.

García-Llorente, M., Harrison, P.A., Berry, P., Palomo, I., Gómez-Baggethun, E., IniestaArandia, I., Montes, C., García del Amo, D., Martín-López, B., 2016. What can conservation strategies learn from the ecosystem services approach? Insights from ecosystem assessments in two Spanish protected areas. Biodivers. Conserv. 1-23. https://doi.org/10.1007/s10531016-1152-4.

García-Nieto, A.P., Quintas-Soriano, C., García-Llorente, M., Palomo, I., Montes, C., MartínLópez, B., 2015. Collaborative mapping of ecosystem services: the role of stakeholders' profiles. Ecosyst. Serv. 13, 141-152. https://doi.org/10.1016/j.ecoser.2014.11.006.

Gieryn, T.F., 1983. Boundary-work and the demarcation of science from nonscience: strains and interests in professional ideologies of scientists. Am. Sociol. Rev. 48, 781-795. https://doi.org/10.2307/2095325.

Gieryn, T.F., 1995. Boundaries of science. In: Jasanoff, S., Markle, G.E., Petersen, J.C., Pinch, T. (Eds.), Handbook of science and technology studies. Sage Publications Inc., Thousand Oaks, California, pp. 393-443.

Gómez-Baggethun, E., Kelemen, E., Martín-López, B., Palomo, I., Montes, C., 2013. Scale misfit in ecosystem service governance as a source of environmental conflict. Soc. Nat. Resour. 26, 1202-1216. https://doi.org/10.1080/08941920.2013.820817.

Gonzalez-Redin, J., Luque, S., Poggio, L., Smith, R., Gimona, A., 2016. Spatial Bayesian belief networks as a planning decision tool for mapping ecosystem services trade-offs on forested landscapes. Environ. Res. 144 (Part B), 15-26.

https://doi.org/10.1016/j.envres.2015.11.009.

Grizzetti, B., Liquete, C., Antunes, P., Carvalho, L., Geama na“, N., Giuca , R., Leone, M., McConnell, S., Preda, E., Santos, R., Turkelboom, F., Va dineanu, A., Woods, H., 2016. Ecosystem services for water policy: insights across Europe. Environ. Sci. Policy 66, 179190. https://doi.org/10.1016/j.envsci.2016.09.006.

Grizzetti, B., Lanzanova, D., Liquete, C., Reynaud, A., Cardoso, A.C., 2016. Assessing water ecosystem services for water resource management. Environ. Sci. Policy 61, 194-203. https://doi.org/10.1016/j.envsci.2016.04.008.

Guston, D.H., 2001. Boundary organizations in environmental policy and science: an introduction. Sci. Technol. Hum. Values 26, 399-408. https://doi.org/10.1177/016224390102600401.

Haase, D., Larondelle, N., Andersson, E., Artmann, M., Borgström, S., Breuste, J., GomezBaggethun, E., Gren, Å., Hamstead, Z., Hansen, R., Kabisch, N., Kremer, P., Langemeyer, J., Rall, E.L., McPhearson, T., Pauleit, S., Qureshi, S., Schwarz, N., Voigt, A., Wurster, D., Elmqvist, T., 2014. A quantitative review of urban ecosystem service assessments: concepts, 
models, and implementation. Ambio 43, 413-433. https://doi.org/10.1007/s13280-014-05040 .

Haberl, H., Winiwarter, V., Andersson, K., Ayres, R.U., Boone, C., Castillo, A., Cunfer, G., Fischer-Kowalski, M., Freudenburg, W.R., Furman, E., Kaufmann, R., Krausmann, F., Langthaler, E., Lotze-Campen, H., Mirtl, M., Redman, C.L., Reenberg, A., Wardell, A., Warr, B., Zechmeister, H., 2006. From LTER to LTSER: conceptualizing the socioeconomic dimension of long-term socioecological research. Ecol. Soc. 11, 13. Available via: http://www.ecologyandsociety.org/vol11/iss2/art13/.

Harrison, P., et al. 2018. Selecting methods for ecosystem service assessment: A decision tree approach. Ecosyst. Serv. 29, 481-498.

Hauck, J., Potschin, M., Saarela, S.-R., Carmen, E., Dick, J., Martín-López, B., Kelemen, E., Keune, H., 2015. Ecosystem services and transdisciplinarity. In: Potschin, M., Jax, K. (Eds.) OpenNESS Ecosystem Service Reference Book. EC FP7 Grant Agreement no. 308428. Available via: www.openness-project.eu/library/reference-book.

Hendriks, K., Braat, L., Deerenberg, C., van Egmond, P., Gaaff, A., van der Heide, M., Jongbloed, R., Klok, C., Leneman, H., Melman, D., Ruijs, A., Tamis, J., 2014. TEEB voor gebieden; Hoofdstudie. Wageningen, Alterra Wageningen UR (University \& Research centre), Alterra-rapport 2489. 166 blz.; 30 fig.; 32 tab.; 114 ref.

http://www.wur.nl/nl/Publicatie-details.htm?publicationId=publication-way-343531373537.

Huutoniemi, K., Klein, J.T., Bruun, H., Hukkinen, J., 2010. Analyzing interdisciplinarity: typology and indicators. Res. Policy 39, 79-88. https://doi.org/10.1016/j.respol.2009.09.011.

Jahn, T., Bergmann, M., Keil, F., 2012. Transdisciplinarity: between mainstreaming and marginalization. Ecol. Econ. 79, 1-10. https://doi.org/10.1016/j.ecolecon.2012.04.017.

Jax, K., Barton, D.N., Chan, K.M.A., de Groot, R., Doyle, U., Eser, U., Görg, C., GómezBaggethun, E., Griewald, Y., Haber, W., Haines-Young, R., Heink, U., Jahn, T., Joosten, H., Kerschbaumer, L., Korn, H., Luck, G.W., Matzdorf, B., Muraca, B., Neßhöver, C., Norton, B., Ott, K., Potschin, M., Rauschmayer, F., von Haaren, C., Wichmann, S., 2013. Ecosystem services and ethics. Ecol. Econ. 93, 260-268. https://doi.org/10.1016/j.ecolecon.2013.06.008.

Jax et al., 2018. Handling a messy world: Lessons learned when trying to make the ecosystem services concept operational. Ecosyst. Serv. 29, 415-427.

Kelemen, E., Nguyen, G., Gomiero, T., Kovács, E., Choisis, J.-P., Choisis, N., Paoletti, M. G., Podmaniczky, L., Ryschawy, J., Sarthou, J.-P., Herzog, F., Dennis, P., Balázs, K., 2013. Farmers' perceptions of biodiversity: lessons from a discourse-based deliberative valuation study. Land Use Policy 35, 318-328. https://doi.org/10.1016/j.landusepol.2013.06.005.

Kelemen, E., Lazányi, O., Arany, I., Aszalós, R., Bela, G., Czúcz, B., Kalóczkai, Á., Kertész, M., Megyesi, B., Gy, P., 2015. Sociocultural valuation of ecosystem services provided by the Kiskunság sand ridge region. Természetvédelmi Közlemények 21, 116-129.

Khagram, S., Nicholas, K.A., Bever, D.M., Warren, J., Richards, E.H., Oleson, K., Kitzes, J., Katz, R., Hwang, R., Goldman, R., Funk, J., Brauman, K.A., 2010. Thinking about knowing: 
conceptual foundations for interdisciplinary environmental research. Environ. Conserv. 37, 388-397. https://doi.org/10.1017/s0376892910000809.

Kloppenburg, J., 1991. Social theory and the de/reconstruction of agricultural science: local knowledge for an alternative agriculture1. Rural Sociol. 56, 519-548.

https://doi.org/10.1111/j.1549-0831.1991.tb00445.x.

Kopperoinen, L., Stange, E., Rusch, G., Baró, F., Garcia Blanco, G., Mederly, P., 2015. Integrating nature-based solutions in urban planning [online]. OpenNESS policy brief No. 3. Available via: http://www.openness-project.eu/sites/default/files/OpenNESS_brief_03.pdf.

Kovács, E., Kelemen, E., Kalóczkai, Á., Margóczi, K., Pataki, G., Gébert, J., Málovics, G., Balázs, B., Roboz, Á., Krasznai Kovács, E., Mihók, B., 2015. Understanding the links between ecosystem service trade-offs and conflicts in protected areas. Ecosyst. Serv. 12, 117127. https://doi.org/10.1016/j.ecoser.2014.09.012.

Kuhn, T.S., 1962. The structure of scientific revolutions fourth ed. 2012. University of Chicago press.

Lakatos, I., 1970. Falsification and the methodology of scientific research. In: Lakatos, I., Musgrave, A. (Eds.), Criticism and the Growth of Knowledge. Cambridge University Press, Cambridge, UK, pp. 91-138.

Lang, D.J., Wiek, A., Bergmann, M., Stauffacher, M., Martens, P., Moll, P., Swilling, M., Thomas, C.J., 2012. Transdisciplinary research in sustainability science: practice, principles, and challenges. Sustain. Sci. 7, 25-43. https://doi.org/10.1007/s11625-011-0149-x.

Langemeyer, J., Gómez-Baggethun, E., Haase, D., Scheuer, S., Elmqvist, T., 2016. Bridging the gap between ecosystem service assessments and land-use planning through Multi-Criteria Decision Analysis (MCDA). Environ. Sci. Policy 62, 45-56.

https://doi.org/10.1016/j.envsci.2016.02.013.

Laurans, Y., Rankovic, A., Billé, R., Pirard, R., Mermet, L., 2013. Use of ecosystem services economic valuation for decision making: questioning a literature blindspot. J. Environ. Manage. 119, 208-219. https://doi.org/10.1016/j.jenvman.2013.01.008.

Liquete, C., Kleeschulte, S., Dige, G., Maes, J., Grizzetti, B., Olah, B., Zulian, G., 2015. Mapping green infrastructure based on ecosystem services and ecological networks: a PanEuropean case study. Environ. Sci. Policy 54, 268-280.

https://doi.org/10.1016/j.envsci.2015.07.009.

Liquete, C., Cid, N., Lanzanova, D., Grizzetti, B., Reynaud, A., 2016. Perspectives on the link between ecosystem services and biodiversity: the assessment of the nursery function. Ecol. Indic. 63, 249-257. https://doi.org/10.1016/j.ecolind.2015.11.058.

Liquete, C., Piroddi, C., Macías, D., Druon, J.-N., Zulian, G., 2016. Ecosystem services sustainability in the Mediterranean Sea: assessment of status and trends using multiple modelling approaches. Sci. Rep. 6, 34162. https://doi.org/10.1038/srep34162. 
Liquete, C., Udias, A., Conte, G., Grizzetti, B., Masi, F., 2016. Integrated valuation of a nature-based solution for water pollution control. Highlighting hidden benefits. Ecosyst. Serv. 22, 392-401. https://doi.org/10.1016/j.ecoser.2016.09.011.

Lyall, C., Meagher, L., Bruce, A., 2015. A rose by any other name? Transdisciplinarity in the context of UK research policy. Futures 65, 150-162.

https://doi.org/10.1016/j.futures.2014.08.009.

Maass, M., Balvanera, P., Bourgeron, P., Equihua, M., Baudry, J., Dick, J., Forsius, M., Halada, L., Krauze, K., Nakaoka, M., Orenstein, D.E., Parr, T.W., Redman, C.L., Rozzi, R., Santos-Reis, M., Swemmer, A.M., Va dineanu, A., 2016. Changes in biodiversity and tradeoffs among ecosystem services, stakeholders, and components of well-being: the contribution of the International Long-Term Ecological Research network (ILTER) to Programme on Ecosystem Change and Society (PECS). Ecol. Soc. 21, (3). https://doi.org/10.5751/ES08587-21033131.

Maes, J., Zulian, G., Thijssen, M., Castell, C., Baró, F., Ferreira, A.M., Melo, J., Garrett, C.P., David, N., Alzetta, C., Geneletti, D., Cortinovis, C., Zwierzchowska, I., Alves, F.L., Cruz, C.S., Blasi, C., Ortí, M.M.A., Attorre, F., Azzella, M.M., Capotorti, G., Copiz, R., Fusaro, L., Manes, F., Marando, F., Marchetti, M., Mollo, B., Salvatori, E., Zavattero, L., Zingari, P.C., Giarratano, M.C., Bianchi, E., Duprè, E., Barton, D., Stange, E., Perez-Soba, M., Eupen, M.v., verweij, P., Vries, A.d., Kruse, H., Polce, C., Cugny-Seguin, M., Erhard, M., Nicolau, R., Fonseca, A., Fritz, M., Teller, A., 2016. Mapping and assessment of ecosystems and their services. Urban Ecosystems. 4th Report Final. Publications Office of the European Union, Luxembourg. doi: 10.2779/625242.

Martínez Pastur, G., Peri, P.L., Lencinas, M.V., García-Llorente, M., Martín-López, B., 2016. Spatial patterns of cultural ecosystem services provision in Southern Patagonia. Landsc. Ecol. 31, 383-399. https://doi.org/10.1007/s10980-015-0254-9.

Martín-López, B., Iniesta-Arandia, I., García-Llorente, M., Palomo, I., Casado-Arzuaga, I., Amo, D.G.D., Gómez-Baggethun, E., Oteros-Rozas, E., Palacios-Agundez, I., Willaarts, B., González, J.A., Santos-Martín, F., Onaindia, M., López-Santiago, C., Montes, C., 2012. Uncovering ecosystem service bundles through social preferences. PLoS ONE 7, e38970. https://doi.org/10.1371/journal.pone.0038970.

Martín-López, B., Gómez-Baggethun, E., García-Llorente, M., Montes, C., 2014. Trade-offs across value-domains in ecosystem services assessment. Ecol. Indic. 37 (Part A), 220-228. https://doi.org/10.1016/j.ecolind.2013.03.003.

Martinez-Harms, M.J., Bryan, B.A., Balvanera, P., Law, E.A., Rhodes, J.R., Possingham, H.P., Wilson, K.A., 2015. Making decisions for managing ecosystem services. Biol. Conserv. 184, 229-238. https://doi.org/10.1016/j.biocon.2015.01.024.

Massey, C., Alpass, F., Flett, R., Lewis, K., Morriss, S., Sligo, F., 2006. Crossing fields: the case of a multi-disciplinary research team. Qual. Res. 6, 131-147.

https://doi.org/10.1177/1468794106062706. 
McCown, R.L., Parton, K.A., 2006. Learning from the historical failure of farm management models to aid management practice. Part 2. Three systems approaches. Aust. J. Agric Res. 57 (2), 157-172. https://doi.org/10.1071/AR05052.

McKenzie, E., Posner, S., Tillmann, P., Bernhardt, J.R., Howard, K., Rosenthal, A., 2014. Understanding the use of ecosystem service knowledge in decision making: lessons from international experiences of spatial planning. Environ. Plan. C Gov. Pract. 32, 320-340. https://doi.org/10.1068/c12292j.

Millennium Ecosystem Assessment, 2005. Ecosystems and Human Well-being: Synthesis. Island Press, Washington, DC.

Nelson, R.A., Holzworth, D.P., Hammer, G.L., Hayman, P.T., 2002. Infusing the use of seasonal climate forecasting into crop management practice in North East Australia using discussion support software. Agric. Syst. 74, 393-414. https://doi.org/10.1016/S0308$521 \mathrm{X}(02) 00047-1$.

Nesshöver, C., Vandewalle, M., Wittmer, H., Balian, E.V., Carmen, E., Geijzendorffer, I. R., Görg, C., Jongman, R., Livoreil, B., Santamaria, L., Schindler, S., Settele, J., Sousa Pinto, I., Török, K., van Dijk, J., Watt, A.D., Young, J.C., Zulka, K.P., 2016. The Network of Knowledge approach: improving the science and society dialogue on biodiversity and ecosystem services in Europe. Biodivers. Conserv. 25, 1215-1233.

https://doi.org/10.1007/s10531-016-1127-5.

Obst, C., Hein, L., Edens, B., 2016. National accounting and the valuation of ecosystem assets and their services. Environ. Resour. Econ. 64, 1-23. https://doi.org/10.1007/s10640015-9921-1.

Palomo, I., Martín-López, B., Potschin, M., Haines-Young, R., Montes, C., 2013. National Parks, buffer zones and surrounding lands: Mapping ecosystem service flows. Ecosyst. Serv. 4, 104-116. https://doi.org/10.1016/j.ecoser.2012.09.001.

Palomo, I., Martín-López, B., Alcorlo, P., Montes, C., 2014. Limitations of protected areas zoning in mediterranean cultural landscapes under the ecosystem services approach. Ecosystems 17, 1202-1215. https://doi.org/10.1007/s10021-014-9788-y.

Posner, S., Getz, C., Ricketts, T., 2016. Evaluating the impact of ecosystem service assessments on decision-makers. Environ. Sci. Policy 64, 30-37. https://doi.org/10.1016/j.envsci.2016.06.003.

Potschin et al., 2018. Understanding the role of conceptual frameworks: Reading the ecosystem service cascade. Ecosyst. Serv. 29, 428-440.

Priess, J.A. et al., 2018. New EU-scale environmental scenarios until 2050 - Scenario process and initial scenario applications. Ecosyst. Serv. 29, 542-551.

Primmer, E., Jokinen, P., Blicharska, M., Barton, D.N., Bugter, R., Potschin, M., 2015. Governance of Ecosystem Services: a framework for empirical analysis. Ecosyst. Serv. 16, 158-166. https://doi.org/10.1016/j.ecoser.2015.05.002. 
Röckmann, C., van Leeuwen, J., Goldsborough, D., Kraan, M., Piet, G., 2015. The interaction triangle as a tool for understanding stakeholder interactions in marine ecosystem based management. Mar. Policy 52, 155-162. https://doi.org/10.1016/j.marpol.2014.10.019.

Saarela, S.-R., Rinne, J., 2016. Knowledge brokering and boundary work for ecosystem service indicators. An urban case study in Finland. Ecol. Indic. Part 61 (Part 1), 49-62. https://doi.org/10.1016/j.ecolind.2015.07.016.

Saarikoski et al., 2018. Institutional challenges in putting ecosystem service knowledge in practice. Ecosyst. Serv. 29, 579-598.

Smith, R., et al., 2018. Operationalising ecosystem service assessment in Bayesian Belief Networks: Experiences within the OpenNESS project. Ecosyst. Serv. 29, 452-464.

Tomintoul and Glenlivet Landscape Partnership 2016. Landscape conservation action plan. Grant application to UK National Heritage Lottery Fund 54pp.

Tenerelli, P., Demšar, U., Luque, S., 2016. Crowdsourcing indicators for cultural ecosystem services: a geographically weighted approach for mountain landscapes. Ecol. Indic. 64, 237248. https://doi.org/10.1016/j.ecolind.2015.12.042.

Tenerelli, P., Püffel, C., Luque, S., 2017. Spatial assessment of aesthetic services in a complex mountain region: combining visual landscape properties with crowdsourced geographic information. Landscape Ecol. https://doi.org/10.1007/s10980-017-0498-7.

The Economics of Ecosystems and Biodiversity (TEEB), 2010. Biodiversity, ecosystems and ecosystem services. In: Kumar, P. (Ed.), The Economics of Ecosystems and Biodiversity: Ecological and Economic Foundation. UNEP/Earthscan, London and Washington, pp. 41112.

Turkelboom et al., 2018. When we cannot have it all: Ecosystem services trade-offs in the context of spatial planning. Ecosyst. Serv. 29, 566-578.

Verweij, P., Simoes, M., Alves, A., Ferraz, R., Cormont, A., 2014. Linking Bayesian Belief Networks and GIS to assess the Ecosystem Integrity in the Brazilian Amazon. Proceedings of the International Environmental Modelling and Software Society (iEMSs), 7th International Congress on Environmental Modelling and Software; 2014. v. 2, p. 864-871.

VSN International, 2013. GenStat for Windows. VSN International, Hemel Hempstead, UK. Available via: http://www.vsni.co.uk/software/genstat/.

Waylen, K.A., Young, J., 2014. Expectations and experiences of diverse forms of knowledge use: the case of the UK National Ecosystem Assessment. Environ. Plan. C Gov. Pract. 32, 229-246. https://doi.org/10.1068/c1327j.

Zulian, G., 2018. Practical application of spatial ecosystem service models to aid decision support. Ecosyst. Serv. 29, 465-480. 